\title{
Safety and probiotic functionality of isolated goat milk lactic acid bacteria
}

\author{
Liliane Andrade da Silva ${ }^{1}$ (1) • Jose Honorio Pereira Lopes Neto ${ }^{1} \cdot$ Haíssa Roberta Cardarelli ${ }^{2}$
}

Received: 16 April 2019 / Accepted: 8 November 2019/Published online: 2 December 2019

(C) The Author(s) 2019

\begin{abstract}
Purpose Lactic acid bacteria (LAB) are traditionally employed in the food industry. LAB strains from goat milk may also present probiotic potential, and it is fundamental to study the safety and functionality aspects which are desirable for their use in food. The objective of this study was to verify the probiotic potential of lactic bacteria isolated from goat milk.

Methods The presence of safety-related virulence factors (hemolytic activity, gelatinase production, coagulase, and sensitivity to antibiotics) as well as functionality (exopolysaccharide (EPS) production, proteolytic activity, autoaggregation, gas production, survival in the gastrointestinal tract, and antimicrobial activity against bacteria that impair oral health) were determined.

Result The selected LAB strains are safe against the evaluated parameters and have characteristics of possible probiotic candidates. Especially L. plantarum (DF60Mi) and Lactococcus lactis (DF04Mi) have potential to be added to foods because they have better resistance to simulated gastrointestinal conditions. In addition, they are isolated with already proven antimicrobial activity against Listeria monocytogenes, an important food-borne pathogen. DF60Mi was able to produce EPS (exopolysaccharides). LS2 and DF4Mi strains, both Lactococcus lactis subsp. lactis, demonstrated antimicrobial activity against S. mutans ATCC 25175, a recurrent microorganism in oral pathologies, mainly caries.

Conclusion This study provides subsidies for future exploration of the potentialities of these LAB strains for both the development of new functional foods and for application in oral health.
\end{abstract}

Keywords Microorganisms $\cdot$ Potentiality $\cdot$ Conservation $\cdot$ Functional foods $\cdot$ Health

\section{Introduction}

Safety aspects of microorganisms, even belonging to a group of bacteria that is generally recognized as safe (GRAS) (Joint FAO/WHO 2002) such as lactic acid bacteria (LAB), involve determining its potential for virulence. Among virulence determinants associated with pathogenicity, resistance to antibiotics and the production of extracellular proteins such as hemolysin and gelatinase, as well as surface proteins and

Liliane Andrade da Silva

liliane_andrade1984@ hotmail.com

1 Postgraduate Program in Food Science and Technology, Department of Food Engineering, Federal University of Paraíba (UFPB), Cidade Universitária, João Pessoa, PB 58051-900, Brazil

2 Department of Food Technology, Center for Technology and Regional Development, Federal University of Paraíba, João Pessoa, Brazil aggregation substances may be highlighted (Yogurtcu and Tuncer 2013; Padmavathi et al. 2018).

Probiotics are "living microorganisms that, when given in adequate amounts, confer a health benefit to the host" (Hill et al. 2014), as well as immunomodulatory effects (Khan 2014; Saadat et al. 2019), which have resulted in considerable interest from health-related industries. Several criteria are used to consider new LAB strains as potentially probiotic, including their tolerance to acid and bile conditions (Vijaya et al. 2015). In addition, probiotic LAB may be capable of producing exopolysaccharides (EPS) and, in this sense, EPS contributes to the formation of bacterial cell aggregates and in the recognition and adhesion to the surface, facilitating colonization of beneficial LAB in several ecosystems (Schiavao-Souza et al. 2007; Saadat et al. 2019). Another aspect to consider is related to the function of these EPS producers LAB on oral health for the prevention of dental caries and/or other diseases of the oral cavity (Bastos et al. 2013). In addition, the oral cavity has a large amount of bacteria, which when unbalanced cause oral diseases. Probiotics have already been introduced 
for the prevention and treatment of these diseases, as they have the ability to modulate the growth of oral bacteria and decrease the salivary levels of cariogenic bacteria, thereby also decreasing the cariogenic potential of dental biofilm (Magno et al. 2019; Bosch et al. 2012; De Souza et al. 2011). Thus, the objective of this study was to investigate the probiotic potentiality of LAB isolated from goat milk regarding its safety and functionality aspects. In this sense, the study found a strain capable to resist to GIT-simulated conditions associated to EPS production which has potential application to functional foods development.

\section{Materials and methods}

\section{Microorganisms}

The microorganisms used are lactic acid bacteria (LAB) isolated from goat milk and presented antimicrobial activity against $L$. monocytogenes. They were identified as Weissella cibaria (LS1), Lactococcus lactis subsp. lactis (LS2, LS3, and DF04Mi), and Lactobacillus plantarum (DF60Mi). The first three were isolated by our research group (De Lima et al. 2017) in the Northeast region of Brazil, and the sequences were assigned as GenBank accession numbers: LS1 (BankIt1779156 KP213176), LS2 (BankIt1779156 KP213177), and LS3 (BankIt1779156 KP213178. The last two were isolated by Furtado et al. (2014) and were given in collaboration by University of São Paulo, and the sequences were assigned DF60Mi (SUB6418339 SeqIDDFMi60F MN560058) and DF04Mi (SUB6418339 SeqIDDFMi60R MN560059). All isolates were activated at $30{ }^{\circ} \mathrm{C}$ in $5 \mathrm{~mL}$ of de Man, Rogosa, and Sharpe (MRS) broth (Himedia, India) for $24 \mathrm{~h}$ to be used in the other analyses.

All analyses of this study were performed in triplicate.

\section{LAB safety analyses}

\section{Hemolytic activity}

Evaluation of hemolytic activity was performed in Brain Heart Infusion (BHI) agar (Himedia, Mumbai, India) supplemented with $5 \%\left(\mathrm{~m} \mathrm{v}^{-1}\right)$ defibrinated sheep blood. The reactivated LABs were scored on plates containing the medium and incubated at $30{ }^{\circ} \mathrm{C}$. After 48 to $72 \mathrm{~h}$, the hemolytic reaction was evaluated by observing both the partial hydrolysis of the red blood cells and the production of a green zone ( $\alpha$-hemolysis), as well as the total hydrolysis of red blood cells producing a clear zone around the bacterial colonies ( $\beta$-hemolysis) or no reaction ( $\gamma$-hemolysis). B-hemolytic activity was confirmed using Staphylococcus aureus strain ATCC 23235 as a positive control (Eaton and Gasson 2001).

\section{Production of gelatinase}

The isolates were streaked with a loop in tubes with nutrient gelatin (peptone $5 \mathrm{~g} \mathrm{~L}^{-1}$, meat extract $3 \mathrm{~g} \mathrm{~L}^{-1}$, and gelatin $120 \mathrm{~g} \mathrm{~L}^{-1}$ ) (Himedia, Mumbai, India) after reactivation and incubated at $30^{\circ} \mathrm{C}$ for $7-14$ days, with the occurrence of liquefaction verified daily, being refrigerated at $4{ }^{\circ} \mathrm{C}$ for $1 \mathrm{~h}$. The production of gelatinase by the isolates is indicated by the liquefaction of the medium and its persistence after refrigeration (hydrolysis of gelatin) (Dela Cruz and Torres 2012).

\section{Coagulase test}

The coagulase assay was performed in $0.3 \mathrm{~mL}$ of the strains incubated aerobically in MRS culture medium (Himedia, Mumbai, India) for 18 to $24 \mathrm{~h}$ at $30^{\circ} \mathrm{C}$, which were transferred to sterile tubes containing $0.3 \mathrm{~mL}$ reconstituted rabbit plasma (Newprov, Pinhais, Paraná, Brazil) and incubated at $30^{\circ} \mathrm{C}$ for 6 h (De Almeida Júnior et al. 2015).

\section{Sensitivity to antibiotics}

The sensitivity of the strains to antibiotics was determined by disc diffusion according to a protocol adapted from García-Hernández et al. (2016). The following antibiotics were tested: ampicillin $(10 \mu \mathrm{g})$, chloramphenicol $(30 \mu \mathrm{g})$, clindamycin $(2 \mu \mathrm{g})$, gentamicin $(10 \mu \mathrm{g})$, and tetracycline $(30 \mu \mathrm{g})$, chosen according to the recommendations proposed by the European Safety Authority of Food (EFSA 2012). Cultures were incubated in MRS agar at $37{ }^{\circ} \mathrm{C}$ for 18 to $24 \mathrm{~h}$. Presence or absence of zones of inhibition was defined as sensitivity or resistance, respectively. LAB with zone of inhibition $\geq 15 \mathrm{~mm}$ for gentamicin, $\geq 18 \mathrm{~mm}$ for chloramphenicol, $\geq 19 \mathrm{~mm}$ for tetracycline and $\geq 14 \mathrm{~mm}$ for clindamycin, and ampicillin were considered sensitive, and considered very sensitive with zone of inhibition $\geq 22 \mathrm{~mm}$. The inhibition zone diameters were interpreted according to EUCAST guidelines (European Committee on Antimicrobial Susceptibility Testing 2014).

\section{Functional LAB analysis}

\section{Determination of exopolysaccharide production (EPS)}

The production of exopolysaccharides by LAB strains was performed according to the method of Angmo et al. (2016), with adaptations as follows: $1 \%\left(\mathrm{v} \mathrm{v}^{-1}\right)$ of the culture previously incubated in MRS (Kasvi, São José dos Pinhais, Paraná, Brazil) was prepared for $24 \mathrm{~h}$ at $30^{\circ} \mathrm{C}$ and added into $50 \mathrm{~mL}$ of the reconstituted medium ( $5 \mathrm{~g}$ skimmed milk powderNestlé, São Paulo, Brazil—with $1 \mathrm{~g}$ glucose [LRG] or with $1 \mathrm{~g}$ of sucrose [LRS]) by incubating for $18-24 \mathrm{~h}$ at $30{ }^{\circ} \mathrm{C}$ 
under rotation at $150 \mathrm{rpm}$ (shaker bed incubator model Luca 223, Lucadema, Brazil). The culture was then centrifuged (Model: 5430R, Eppendorf, Germany) at $8000 \times \mathrm{g}$ for $20 \mathrm{~min}$ at $4{ }^{\circ} \mathrm{C}$ and the supernatant was collected. Three times the volume of ethanol $70 \%\left(\mathrm{v} \mathrm{v}^{-1}\right)$ (Danquímica, Santa Rita, Paraíba, Brazil) was added to the supernatant and incubated under refrigeration at approximately $4{ }^{\circ} \mathrm{C}$ for $15 \mathrm{~h}$ for EPS precipitation. The precipitated EPS was collected by centrifugation at $4000 \times \mathrm{g}$ for $20 \mathrm{~min}$ and oven dried at $50{ }^{\circ} \mathrm{C}$ (Model Luca 223, Lucadema/Brazil).

\section{Determination of proteolytic activity}

The LAB isolates were plated on milk agar to evaluate their proteolytic activity. The medium was prepared by adding $1 \%$ skimmed milk powder to the Plate Count Agar medium (Himedia, India) (Beerens et al. 1990). Plates were incubated at $7{ }^{\circ} \mathrm{C}$ for 10 days and $37^{\circ} \mathrm{C}$ for $48 \mathrm{~h}$. The halo-forming transparent colonies were considered positive for proteolytic activity.

\section{Determination of self-aggregation capacity}

The determination of self-aggregation capacity was performed according to the method described by $\mathrm{Xu}$ et al. (2009) with modifications. Freshly cultured bacterial cells $(20 \mathrm{~mL})$ were centrifuged at $6000 \times \mathrm{g}$ for $10 \mathrm{~min}$ at room temperature at $25{ }^{\circ} \mathrm{C}$ (Model: 5430R, Eppendorf, Germany). The cell pellet was washed twice with phosphate buffer (PBS) (82.0 g NaCl (Vetec, Brazil), $10.5 \mathrm{~g}$ $\mathrm{Na}_{2} \mathrm{HPO}_{4}$ (Vetec, Brazil), and $3.55 \mathrm{~g} \mathrm{NaH} \mathrm{PO}_{4}+\mathrm{H}_{2} \mathrm{O}$ (Vetec, Brazil) and completed with $1 \mathrm{~L}$ of distilled water] at $\mathrm{pH} 7.4$, resuspended again in PBS until the absorbance reached $0.5 \pm 0.02$ at $600 \mathrm{~nm}(0 \mathrm{~h})$. Then, each bacterial suspension $(2 \mathrm{~mL})$ was shaken on a vortex type stirrer (Model: EEQ 9033, Edutec, Brazil) for $10 \mathrm{~s}$ and incubated at $37{ }^{\circ} \mathrm{C}$ for $2 \mathrm{~h}$. After incubation, the bacterial suspension was centrifuged under the same initial conditions, and $1 \mathrm{~mL}$ of the supernatant was removed to measure the absorbance at $600 \mathrm{~nm}$ (A $2 \mathrm{~h}$ ). The percentage of selfaggregation was expressed as:

\section{$1-($ A 2 h/A 0 h) $\times 100$}

\section{Determination of gas production}

Gas production from glucose was evaluated using MRS broth added $3 \%$ glucose in test tubes containing inverted Durham tubes according to the method of Cai et al. (1999).

\section{Determination of the antimicrobial activity of LAB isolates against microorganisms of interest in oral cavity}

Probiotics have shown potential to modulate the growth of oral bacteria responsible for biofilm formation and caries production (Schwendicke et al. 2017; Samot and Badet 2013; Bosch et al. 2012; De Souza et al. 2011); thus, it is important to evaluate the antimicrobial activity of new lactic acid bacteria considering the ability to inhibit microorganisms responsible for caries and other oral diseases. For that, some cariogenic and biofilm-forming bacteria already cited in the literature (Moreira et al. 2009; Da Silva-Boghossian et al. 2011) were selected and provided in collaboration by the team of the Oral Biology Laboratory (Federal University where they were registered (Escherichia coli ATCC 25922, Enteroccus faecalis ATCC 14506, Streptoccus mutans ATCC 25175 , Staphylococcus aureus ATCC 14506, Pseudomonas aeruginosa ATCC 27853, Aggregatibacter actinomycetemcomitans ATCC 29522). Streptoccus mutans stand out as the main producer of caries (Schwendicke et al. 2017; Samot and Badet 2013; Bosch et al. 2012; Da SilvaBoghossian et al. 2011). The evaluation was performed by the "spot on the lawn" adapted from Reenen (1998). The isolates of Weissella cibaria and Lactococcus lactis subsp. lactis were activated in MRS broth incubated for 18 to $24 \mathrm{~h}$ at $37^{\circ} \mathrm{C}$. In parallel, the cariogenic strains were reactivated in BHI broth for 18 to $24 \mathrm{~h}$ at $37^{\circ} \mathrm{C}$ and later standardized with optical density of 0.9 . BHI agar plates containing each of the standardized cariogenic bacteria were prepared in order to achieve viability of $8 \mathrm{Log} \mathrm{CFU} \mathrm{mL}^{-1}$, which received an $8 \mathrm{~mL}$ overlay of MRS after solidification and then a drop of $20 \mu \mathrm{L}$ of each $\mathrm{LAB}$, and were incubated at $37^{\circ} \mathrm{C}$ for $24 \mathrm{~h}$ in aerobiosis, except those containing $S$. mutans which were incubated in anaerobiosis. Inhibition of cariogenic bacteria multiplication was observed through the forming of inhibition zones (halos) around the droplet; their diameters were measured with a caliper and considered as having antimicrobial activity according to Jacobsen et al. (1999).

\section{Viability determination of LAB isolates under simulated gastrointestinal conditions}

The viability determination of the LAB isolates under simulated gastrointestinal conditions followed the methodologies adopted by Vinderola et al. (2008) and Buriti et al. (2010), with modifications. LAB isolates were activated and recultured for two consecutive days. The last peal was performed in a falcon-type centrifuge tube with $20 \mathrm{~mL}$ of the same medium. After the incubation period, the cultures were centrifuged at $2750 \times \mathrm{g}$ for $15 \mathrm{~min}$ at $4{ }^{\circ} \mathrm{C}$ and the supernatant was discarded. The pellet was resuspended in $2 \mathrm{~mL}$ of $0.1 \%$ $\left(\mathrm{m} \mathrm{v}^{-1}\right)$ peptone water (Himedia, India) standardized at 0.9 
density at $625 \mathrm{~nm}$ absorbance, and cell viability was assessed using serial decimal dilution and plating at surface in MRS agar medium (Himedia, India). Next, $5 \%\left(\mathrm{v} \mathrm{v}^{-1}\right)$ of each culture was inoculated into $10 \mathrm{~mL}$ of the gastric juice (acid solution $\mathrm{pH} 3.35$-adjusted with sterile $1 \mathrm{M} \mathrm{HCl}$-plus $3 \mathrm{~g} \mathrm{~L}^{-1}$ pepsin) and vials containing this initial solution were incubated at $37^{\circ} \mathrm{C}$ for $2 \mathrm{~h}$ with shaking at $150 \mathrm{rpm}$ (gastric phase) (incubator shaker model Luca 223, Lucadema/Brazil). After this period, a $1 \mathrm{~mL}$ aliquot was taken to assess cell viability and the $\mathrm{pH}$ of the solution was changed to 5.2 (solution containing $150 \mathrm{~mL} 1 \mathrm{M} \mathrm{NaOH}$ plus $14 \mathrm{~g} \mathrm{PO}_{4} \mathrm{H}_{2} \mathrm{Na}_{2} 2 \mathrm{H}_{2} \mathrm{O} \mathrm{L}{ }^{-1}$ ). The bile $\left(10 \mathrm{~g} \mathrm{~L}^{-1}\right)$ and pancreatin $\left(1 \mathrm{~g} \mathrm{~L}^{-1}\right)$ salts were added and the solutions were incubated at $37^{\circ} \mathrm{C}$ for $2 \mathrm{~h}$ under stirring (enteric phase 1). After the incubation period, an aliquot of the solution was withdrawn again for evaluating cell viability as described above, and the $\mathrm{pH}$ was adjusted to the range of 6.7 to 7.1, while also adjusting the bile salts and pancreatin concentrations according to the new obtained volume. The solution was incubated again under the same initial conditions, totaling $6 \mathrm{~h}$ of incubation under agitation (enteric phase 2) and cell viability was evaluated again. All tests were performed in triplicate, and the results were analyzed by ANOVA and Tukey's test, using Sisvar: a Guide for its Bootstrap procedures in multiple comparisons $5.6 \mathrm{pt}$. software version 2014 (Lavras, Minas Gerais, Brazil).

\section{Results and discussion}

The strains of the same species studied showed different safety and probiotic potential. Some studies also report strains of the same species with different technological characteristics, such as Leuconostoc strains presenting probiotic potential (Jeronymo-Ceneviva et al. 2014), or bacteriocinogenic activity (Arakawa et al. 2016), and also as an exopolysaccharide producing strain (Joshi and Koijam 2014).

\section{Determination of virulence factors}

All evaluated LAB isolated strains presented no $\beta$-hemolytic activity, and this meets the safety requirements as previously reported by Angmo et al. (2016). In addition, the isolated strains also did not produce the virulence-related enzymes gelatinase and coagulase. Lactobacillus spp., Lactococcus spp., and Weissella spp. were not previously reported as $\beta$ hemolysis producers. Saelim et al. (2017) did not find any type of hemolytic activity (either alpha or beta) in L. plantarum $\mathrm{S} 0 / 7$, or in nine Weissella strains (Jeong and Lee 2015), reinforcing its safety and potential application as probiotics in foods. The use of $L$. plantarum in products with probiotic claims is widely disseminated commercially. This is due to the fact that lack of hemolytic activity is considered a requirement for classifying bacteria as GRAS according to EFSA (European Food Safety Authority) (Lee et al. 2014).

Evaluating the antibiotic susceptibility of LAB isolate candidates for probiotic use is essential, as they can be hosts of antibiotic resistance genes and allow their transfer to pathogenic bacteria (De Almeida Júnior et al. 2015). All LAB isolates evaluated in this study were considered to be sensitive to the antibiotics ampicillin, gentamicin, chloramphenicol, tetracycline, and clindamycin (Table 1).

In fact, several studies have shown that LABs are often sensitive to several antibiotics (Angmo et al. 2016; GarcíaHernández et al. 2016). Ren et al. (2014) observed sensitivity of Lactobacillus spp. to tetracycline, clindamycin, streptomycin, ampicillin, gentamicin, chloramphenicol, erythromycin, and penicillin. Costa et al. (2013) found that Weissella paramesenteroides and four species of Lactobacillus (L. casei, L. rhamnosus, L. plantarum, and L. hilgardii) were sensitive against tetracycline. Weisella spp. strains were susceptible to ampicillin, chloramphenicol, erythromycin, and tetracycline (Jeong and Lee 2015), although there are reports that Lactobacillus spp. strains may be commonly resistant to antibiotics such as chloramphenicol (Liu et al. 2009; Argyri et al. 2013). In addition, the resistance of the same genus isolates to gentamicin, tetracycline, and ampicillin (Argyri et al. 2013) was recorded.

\section{Production of EPS and proteolytic activity}

Regarding the EPS production, the DF60Mi strain was the only isolated strain capable of producing this secondary metabolite; however, none of the isolated strains presented proteolytic activity. Lactic bacteria are usually not proteolytic, but act as such when they have limited nutrient content or low amino acid synthesis power, requiring an extra supply (Tavares et al. 2009). Although these bacteria are not strongly proteolytic, proteolytic activity is essential to favor LAB multiplication in milk and allows the development of flavor in dairy products (De Almeida Júnior et al. 2015). On the other hand, according to Oberg et al. (1991), this activity can be undesirable for applying these microorganisms in some cheeses such as Mozzarella, because the cultures have different proteolytic activities, thus altering a final product characteristic, mainly in cheese protein network and melting capacity of the cheese.

Additionally, most of the knowledge acquired with Lactococcus lactis, considered as the LAB family model, groups Lactococcus, Lactobacillus, Leuconostoc, Pediococcus, and Streptococcus. What was identified in these species was the presence of proteolytic enzymes characterized by their role in nutrition and a significant number of putative proteolytic enzymes of unknown functions. Despite this fact, these LABs are not considered highly proteolytic compared to bacilli (Juillard et al. 2016). 
Table 1 Sensitivity of LAB strains to antibiotics and its autoaggregation capacity

\begin{tabular}{|c|c|c|c|c|c|c|c|}
\hline \multirow[t]{2}{*}{ Isolates } & \multicolumn{2}{|l|}{ Autoaggregation } & \multicolumn{5}{|l|}{ Antibiotics } \\
\hline & Species & Autoaggregation $(\%) *$ & AMP $(10 \mu \mathrm{g})$ & GENT $(10 \mu \mathrm{g})$ & CLO $(30 \mu \mathrm{g})$ & TET $(30 \mu \mathrm{g})$ & CLI $(2 \mu \mathrm{g})$ \\
\hline LS1 & Weissella cibaria & $91.47 \pm 0.85$ & ++ & + & + & + & + \\
\hline LS2 & Lactococcus lactis subsp. lactis & $89.68 \pm 2.62$ & ++ & + & + & ++ & + \\
\hline LS3 & Lactococcus lactis subsp. lactis & $93.38 \pm 0.06$ & ++ & + & + & ++ & + \\
\hline DF04Mi & Lactococcus lactis subsp. lactis & $89.68 \pm 3.39$ & ++ & + & + & + & + \\
\hline DF60Mi & Lactobacillus plantarum & $84.24 \pm 3.77$ & ++ & + & ++ & + & ++ \\
\hline
\end{tabular}

* Percentage of autoaggregation expressed as mean \pm standard deviation, $n=3$. AMP, ampicillin; GENT, gentamicin; CLO, chloramphenicol; TET, tetracycline; $C L I$, clindamycin; +, sensitive, zone of inhibition $\geq 15 \mathrm{~mm}$ for GENT, $\geq 18 \mathrm{~mm}$ for CLO, $\geq 19 \mathrm{~mm}$ for TET, $\geq 14 \mathrm{~mm}$ for CLIN and AMP; ++, very sensitive, with inhibition zone $\geq 22 \mathrm{~mm}$

EPS production may present importance among probiotic microorganism candidates (Schiavao-Souza et al. 2007; Angmo et al. 2016; Abushelaibi et al. 2017). Patel et al. (2014) reported 17 probiotic candidates as producers of EPS and endowed with antagonistic activity against Gram-positive microorganisms and Gram-negative pathogens, such as Lactobacillus plantarum 86 and Weissella cibaria 92, belonging to the same species as the tested DF60Mi and LS1 isolates, respectively, which also had previously identified anti-Listeria monocytogenes activity (results not shown).

The probiotic survival can be influenced by the EPS produced by lactic acid bacteria (LAB) during the gastrointestinal transit (Caggianiello et al. 2016). According to Ren et al. (2014), L. plantarum (1557), isolated from vegetable, showed probiotic properties in addition to considerable production of EPS. The probiotic survival could depend on EPS produced by the probiotic strain and, therefore $L$. plantarum has this combined ability also associated to EPS production to be converted into probiotic and prebiotic ingredients (Silva et al. 2019).

\section{Autoaggregation ability}

Another important point is the autoaggregation of LAB. The autoaggregation of microorganisms is related to their adhesion capacity to the intestinal epithelium and is therefore an important requirement for them to be integrated into the intestinal microbiota and consequently to be able to protect the gastrointestinal tract of the host by competition with pathogens and immunomodulatory action. Therefore, the self-aggregation capacity can be used as one of the parameters to select a bacterium with probiotic potential (Xu et al. 2010).

The five isolates tested presented high percentage of autoaggregation, ranging from $84.24 \pm 3.77$ to $93.38 \pm$ $0.06 \%$ (Table 1). Similar results were observed for Lactobacillus spp. with beneficial properties and probiotic characteristics (Todorov et al. 2008; Todorov et al. 2011). In contrast, Espeche et al. (2012) reported low percentages (0$14 \%$ ) of autoaggregation in $43 \mathrm{LAB}$ isolates of raw milk.
Autoaggregation values not necessarily mean an in vivo adhesion, because host factors are involved, such as defense mechanisms, resident microbiota, and peristaltic flow that can modify the bacterial adhesion (Caggia et al. 2015).

\section{Gas production}

Gas production is evaluated as a functionality parameter, aiming to classify the isolates as homo or heterofermentative. This classification is desirable to make the future choice of the food matrix which may receive the potentially probiotic microorganism. Regarding gas production, none of the strains studied presented gas production capacity from glucose, thus presenting homofermentative metabolism. Some obligatory homofermentative species have already been tested to be used as probiotics in humans: L. acidophilus, L. crispatus, L. amylovarus, L. gallinarum, L. gasseri, and L. johnsonii (Ferreira 2012). In contrast, De Almeida Júnior et al. (2015) found $12 \%$ of LAB isolates with gas production capacity. LAB gas production may be technologically necessary in some products such as kefir and some cheeses (Leite et al. 2013; Pedersen et al. 2013) or undesirable in others (Franciosi et al. 2009).

\section{Viability of LAB strains under simulated gastrointestinal tract conditions (GIT)}

It is extremely important that bacteria with probiotic potential are able to tolerate acid and bile stresses, since the ability of the probiotic to survive in adequate numbers after being subjected to gastric acidity (low $\mathrm{pH}$ ) and intestinal condition (bile salts) is important for application in the food industry (Chalas et al. 2016). Also, such beneficial bacteria are usually administered orally via fermented foods, for instance, and they must have the ability to survive the conditions previously mentioned, since it is one of the important criteria for the selection of probiotics (Verón et al. 2017). 
The initial viability of the five LAB isolated strains showed similar behavior (Fig. 1), decreasing after $2 \mathrm{~h}$ of incubation at $37^{\circ} \mathrm{C}$ under acidic conditions (gastric phase) $(p<0.05)$.

Cell viability decreased over the $6 \mathrm{~h}$ of incubation $(p<0.05)$. The DF04Mi and DF60Mi isolates showed high resistance after $4 \mathrm{~h}(6.80 \pm 0.17 \mathrm{Log} \mathrm{CFU} / \mathrm{mL} ; 6.06 \pm 0.01$ $\log \mathrm{CFU} / \mathrm{mL})$ and $6 \mathrm{~h}(6.16 \pm 0.15 \mathrm{Log} \mathrm{CFU} / \mathrm{mL} ; 6.00 \pm$ $0.01 \mathrm{Log} C F U / \mathrm{mL})$, respectively, of incubation under the same conditions of temperature and agitation. LS1, LS2, and LS3 had viability not detected after $4 \mathrm{~h}$. Therefore, the acid and bile tolerances of all the isolates varied $(p<0.05)$. In the case of LS1, LS2, and LS3, it is possible that cells were injured because the previous step (gastric phase), precluding a possible recovery (Madureira et al. 2011; De Oliveira et al. 2014). Dubey and Jeevaratnam (2015) and Das et al. (2016) studied lactic bacteria for probiotic characterization that presented resistance to an acid environment and were similar to the results found in this study. Contrarily, Angmo et al. (2016) reported variability in the survival of lactic acid bacteria exposed to gastric juice under simulated conditions in vitro, but with little or no impact on the viability of most of the strains studied, with L. casei being the most tolerant among all isolated $\mathrm{LAB}$.

Acid tolerance of bacteria is important not only to support gastric stress, but also as a prerequisite for its use as dietary adjuncts; in addition, it allows the strains to survive longer in foods with a high acid content. With respect to bile salt tolerance, in this case, it is a prerequisite for the colonization and metabolic activity of bacteria in the small intestine of the host, thus contributing to the balance of the intestinal microflora (Shehata et al. 2016). Abuhelabi et al. (2017) observed that
LAB isolates selected from camel milk showed probiotic characteristics, especially L. plantarum KX881779 and Lactococcus lactis KX881782 with great potential for use in food. The results were equivalent to that identified in this study, where the best probiotic potentials were DF60Mi and DF04Mi, L. plantarum spp., and Lactococcus lactis spp., respectively.

\section{Determination of the antimicrobial activity of LAB isolates against microorganisms of interest in oral health}

Among the tested isolated strains, it was identified that LS2 and DF04Mi, both Lactococcus lactis subsp. lactis, presented antimicrobial activity against $S$. mutans (Table 2), presenting halos with a diameter of $10 \mathrm{~mm}$ and $13 \mathrm{~mm}$, respectively. Schwendicke et al. (2017) reported some probiotic lactic acid bacteria with antimicrobial activity and inhibition of biofilm formation formed by S. mutans. However, other in vitro and clinical studies have produced ambiguous results regarding the benefits or risks associated with caries prevention through the use of probiotic lactic acid bacteria.

While some studies have reported a reduced viability of cariogenic bacteria after probiotic bacteria testing (Gruner et al. 2016), others do not confirm these effects (Keller et al. 2012; Taipale et al. 2012). This probably occurs due to a lack of knowledge on the exact interference mechanisms of probiotic lactic acid bacteria in the caries formation process (Lang et al. 2010). Thus, other clinical studies should be developed to safely evaluate whether the tested bacteria actually have inhibitory activity against caries produced by $S$. mutans.

\section{BALs' resistance to TGI}

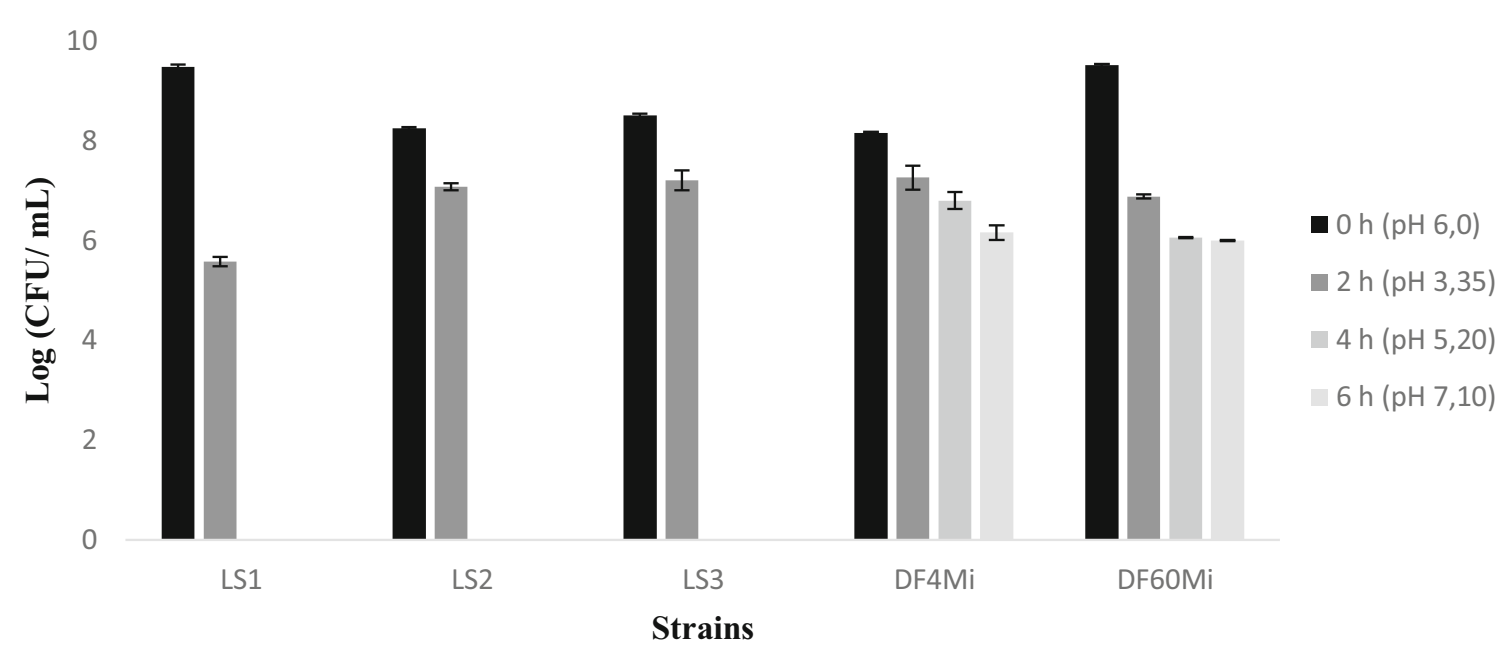

Fig. 1 LAB resistance in simulated gastrointestinal tract (GIT) conditions of LS1, LS2, LS3, DF4Mi, and DF60Mi strains over time. a-d Means

followed by different lowercase letters differ statistically over time for the same strain (Tukey's test, $p<0.05$ ) 
Table 2 Antimicrobial activity against microorganisms of interest in oral health

\begin{tabular}{lllllll}
\hline Antimicrobial activity & \multicolumn{1}{l}{} \\
\hline Isolates & $\begin{array}{l}\text { E.coli ATCC } \\
25922\end{array}$ & $\begin{array}{l}\text { E. faecalis ATCC } \\
14506\end{array}$ & $\begin{array}{l}\text { S. mutans ATCC } \\
25175\end{array}$ & $\begin{array}{l}\text { S. aureus ATCC } \\
14506\end{array}$ & $\begin{array}{l}\text { P. aeruginosa ATCC } \\
27853\end{array}$ & $\begin{array}{l}\text { A. actinomycetemcomitans } \\
\text { ATCC 29522 }\end{array}$ \\
\hline LS1 & - & - & - & - & - & - \\
LS2 & - & - & + & - & - & - \\
LS3 & - & - & - & - & - & - \\
DF04Mi - & - & + & - & - & - \\
DF60Mi - & - & - & - & - & - \\
\hline
\end{tabular}

(-) no inhibition

\section{Conclusion}

Selected isolates from goat milk showed potentially probiotic characteristics according to the reported safety and functionality results. In particular, L. plantarum (DF60Mi) and Lactococcus lactis (DF04Mi) have potential to possibly be used in food due to the gastric and enteric resistance presented in simulated GIT conditions, in addition to not presenting virulence characteristics as the other strains studied. LS2 and DF04Mi, both Lactococcus lactis subsp. lactis, are worth noting because they demonstrate antimicrobial activity against S. mutans, a recurrent microorganism in oral pathologies (mainly caries), and the benefits they can promote to oral health need to be further studied. Therefore, considering the particular abilities found in this study, it is possible to explore the use of these potentially probiotic bacteria isolated from goat milk from two regions of Brazil for future application in food fermented production.

Acknowledgments The authors thank the Federal Agency for Support and Evaluation of Graduate Studies (CAPES) for the scholarships granted; to Professor Dr. Fábio Correia Sampaio and the Laboratory of Oral Biology team (Federal University of Paraíba); to Professor Dr. Bernadette D.G. M. Franco and Danielle Nader Furtado (University of São Paulo) for their assistance in studies on antimicrobial action in oral health and for the use of LAB strains (DF04Mi and DF60Mi), respectively.

Funding This study received research grants from funding agencies (Brazilian Federal Agency for the Support and Evaluation of Graduate Education (Coordenação de Aperfeiçoamento de Pessoal de Nível Superior - CAPES)).

\section{Compliance with ethical standards}

Conflict of interest The authors declare that they have no conflicts of interest.

Research involving human participants and/or animals This article does not contain any studies with human participants or animals performed by any of the authors.
Open Access This article is distributed under the terms of the Creative Commons Attribution 4.0 International License (http:// creativecommons.org/licenses/by/4.0/), which permits unrestricted use, distribution, and reproduction in any medium, provided you give appropriate credit to the original author(s) and the source, provide a link to the Creative Commons license, and indicate if changes were made.

\section{References}

Abushelaibi A, Al-Mahadin S, El-Tarabily K, Shah NP, Ayyash M (2017) Characterization of potential probiotic lactic acid bacteria isolated from camel milk. LWT-Food Science and Technology 79:316-325

Angmo K, Kumari A, Bhalla TC (2016) Probiotic characterization of lactic acid bacteria isolated from fermented foods and beverage of Ladakh. LWT Food Sci Technol 66:428-435

Arakawa K, Yoshida S, Aikawa H, Hano C, Bolormaa T, Burenjargal S, Miyamoto T (2016) Production of a bacteriocin-like inhibitory substance by Leuconostoc mesenteroides subsp. dextranicum 213M0 isolated from Mongolian fermented mare milk, airag. Anim Sci J 87(3):449-456

Argyri AA, Zoumpopoulou G, Karatzas KAG, Tsakalidou E, Nychas GJE, Panagou EZ, Tassou CC (2013) Selection of potential probiotic lactic acid bacteria from fermented olives by in vitro tests. Food Microbiol 33(2):282-291

Bastos EM, Brito F, Da SIlva RM, Fischer RG, Da Silva Figueredo CM (2013) Probióticos na terapia periodontal. Revista Brasileira de Odontologia 69(2):224

Beerens H, Luquet FM, Oria Almudí RM (1990) Guía práctica para el análisis microbiológico de la leche y los productos lácteos. Zaragoza, Embrapa Rondônia 1:151

Bosch M, Nart J, Audivert S, Bonachera MA, Alemany AS, Fuentes MC, Cuné J (2012) Isolation and characterization of probiotic strains for improving oral health. Arch Oral Biol 57(5):539-549

Buriti FC, Castro IA, Saad SM (2010) Viability of Lactobacillus acidophilus in synbiotic guava mousses and its survival under in vitro simulated gastrointestinal conditions. Int J Food Microbiol 137(2-3):121-129

Caggia C, De Angelis M, Pitino I, Pino A, Randazzo C (2015) Probiotic features of Lactobacillus strains isolated from Ragusano and pecorino Siciliano cheeses. Food Microbiol 50:109-117

Cai Y, Suyanandana P, Saman P, Benno Y (1999) Classification and characterization of lactic acid bacteria isolated from the intestines of common carp and freshwater prawns. J Gen Appl Microbiol 45(4):177-184 
Caggianiello G, Kleerebezem M, Spano G (2016) Exopolysaccharides produced by lactic acid bacteria: from health-promoting benefits to stress tolerance mechanisms. Applied Microbiology Biotechnology 100:3877-3886

Chalas R, Janczarek M, Bachanek T, Mazur E, Cieszko-Buk M, Szymanska J (2016) Characteristics of oral probiotics-a review. Current Issues in Pharmacy and Medical Sciences 29(1):8-10

Costa HHS, Souza MR, Acúrcio LB, Cunha AF, Resende MFS, Nunes ÁC (2013) Probiotic potential of lactic acid bacteria isolated from minas artisanal cheese from Serra da Canastra, MG. Arquivo Brasileiro de Medicina Veterinária e Zootecnia 65(6):1858-1866

De Souza CDVA, Junior RH, Maia KD, De Uzeda M, De Carvalho WS (2011) Efeitos do consumo diário de probiótico sobre a microbiota cariogênica. Revista Brasileira de Odontologia 68(1):128

Da Silva-Boghossian CM, Do Souto RM, Luiz RR, Colombo APV (2011) Association of red complex. A actinomycetemcomitans and non-oral bacteria with periodontal diseases Archives of oral biology 56(9):899-906

Das P, Khowala S, Biswas S (2016) In vitro probiotic characterization of Lactobacillus casei isolated from marine samples. LWT Food Sci Technol 73:383-390

De Almeida Júnior WLG, da Silva FÍ, de Souza JV, da Silva CDA, da Costa MM, Dias FS (2015) Characterization and evaluation of lactic acid bacteria isolated from goat milk. Food Control 53:96-103

De Lima EDLC, de Moura FJ, Cardarelli HR (2017) Optimized fermentation of goat cheese whey with Lactococcus lactis for production of antilisterial bacteriocin-like substances. LWT Food Sci Technol 84: 710-716

De Oliveira MEG, Garcia EF, De Oliveira CEV, Gomes AMP, Pintado MME, Madureira ARMF, Da Conceição ML, Queiroga RCRE, De Souza EL (2014) Addition of probiotic bacteria in a semi-hard goat cheese (coalho): survival to simulated gastrointestinal conditions and inhibitory effect against pathogenic bacteria. Food Res Int 64: 241-247

Dela Cruz TEE, Torres JMO (2012) Gelatin hydrolysis test protocol. American Society for Microbiology 1:10

Dubey AK, Jeevaratnam K (2015) Probiotic screening of Lactobacilli isolates from Uttapam batter fermented supplementing with Piper betle L. leaves. Advances in Microbiology 5(13):858

Eaton TJ, Gasson MJ (2001) Molecular screening of Enterococcus virulence determinants and potential for genetic exchange between food and medical isolates. Appl Environ Microbiol 67(4):1628-1635

Espeche MC, Pellegrino M, Frola I, Larriestra A, Bogni C, Nader-Macías MF (2012) Lactic acid bacteria from raw milk as potentially beneficial strains to prevent bovine mastitis. Anaerobe 18(1):103-109

EFSA Panel on Additives and Products or Substances used in Animal Feed (FEEDAP) (2012) Guidance on the assessment of bacterial susceptibility to antimicrobials of human and veterinary importance. EFSA J 10(6):2740

European Committee on Antimicrobial Susceptibility Testing. (2014). Breakpoint tables for interpretation of MICs and zone diameters. Version 3.1 EUCAST; 2013

Ferreira CLDLF (2012) Prebióticos e probióticos: atualização e prospecção. Rubio Press, Rio de Janeiro

Food and Agriculture Organization - International [FAO/WHO] (2002) Probiotics in food: health and nutritional properties and guidelines for evaluation. Report of a joint FAO/WHO working Group on Drafting Guidelines for the Evaluation of Probiotics in Food. World Health Organization, London Ontario, Canada

Franciosi E, Settanni L, Cavazza A, Poznanski E (2009) Biodiversity and technological potential of wild lactic acid bacteria from raw cows' milk. Int Dairy J 19(1):3-11

Furtado DN, Todorov SD, Landgraf M, Destro MT, Franco BD (2014) Bacteriocinogenic Lactococcus lactis subsp. lactis DF04Mi isolated from goat milk: characterization of the bacteriocin. Braz J Microbiol 45(4):1541-1550
García-Hernández Y, Pérez-Sánchez T, Boucourt R, Balcázar JL, Nicoli JR, Moreira-Silva J, Halaihel N (2016) Isolation, characterization and evaluation of probiotic lactic acid bacteria for potential use in animal production. Res Vet Sci 108:125-132

Gruner D, Paris S, Schwendicke F (2016) Probiotics for managing caries and periodontitis: systematic review and meta-analysis. J Dent 48: $16-25$

Hill C, Guarner F, Reid G, Gibson GR, Merenstein DJ, Pot B, Calder PC (2014) The International Scientific Association for Probiotics and Prebiotics consensus statement on the scope and appropriate use of the term probiotic. Nat Rev Gastroenterol Hepatol 11(8):506-514

Jacobsen CN, Nielsen VR, Hayford AE, Møller PL, Michaelsen KF, Paerregaard A, Sandstro B, Tvede MM, Jakobsen M (1999) Screening of probiotic activities of forty-seven strains of Lactobacillus spp. by in vitro techniques and evaluation of the colonization ability of five selected strains in humans. Appl. Environ. Microbiol 65(11):4949-4956

Jeong DW, Lee JH (2015) Antibiotic resistance, hemolysis and biogenic amine production assessments of Leuconostoc and Weissella isolates for kimchi starter development. LWT Food Sci Technol 64(2):10781084

Jeronymo-Ceneviva AB, De Paula AT, Silva LF, Todorov SD, Franco BDGM, Penna ALB (2014) Probiotic properties of lactic acid bacteria isolated from water-buffalo mozzarella cheese. Probiotics and antimicrobial proteins 6(3-4):141-156

Joshi SR, Koijam K (2014) Exopolysaccharide production by a lactic acid bacteria, Leuconostoc lactis isolated from ethnically fermented beverage. National Academy Science Letters 37(1):59-64

Juillard V, Lopez-Kleine L, Monnet V (2016) Proteolytic systems of lactic acid bacteria (LAB). Institut National de la Recherche Agronomique 1:7

Keller MK, Hasslöf P, Dahlén G, Stecksén-Blicks C, Twetman S (2012) Probiotic supplements (Lactobacillus reuteri DSM 17938 and ATCC PTA 5289) do not affect regrowth of mutans streptococci after full-mouth disinfection with chlorhexidine: a randomized controlled multicenter trial. Caries Res 46(2):140-146

Khan US (2014) Probiotics in dairy foods: a review. Nutrition \& Food Science 44(1):71-88

Lang C, Böttner M, Holz C, Veen M, Ryser M, Reindl A, Tanzer JM (2010) Specific lactobacillus/mutans streptococcus co-aggregation. J Dent Res 89(2): 175-179

Lee NK, Kim SY, Han KJ, Eom SJ, Paik HD (2014) Probiotic potential of Lactobacillus strains with anti-allergic effects from kimchi for yogurt starters. LWT Food Sci Technol 58(1):130-134

Leite AMO, Leite DCA, Del Aguila EM, Alvares TS, Peixoto RS, Miguel MAL, Paschoalin VMF (2013) Microbiological and chemical characteristics of Brazilian kefir during fermentation and storage processes. J Dairy Sci 96(7):4149-4159

Liu J, Luo J, Ye H, Sun Y, Lu Z, Zeng X (2009) Production, characterization and antioxidant activities in vitro of exopolysaccharides from endophytic bacterium Paenibacillus polymyxa EJS-3. Carbohydr Polym 78(2):275-281

Madureira AR, Amorim M, Gomes AM, Pintado ME, Malcata FX (2011) Protective effect of whey cheese matrix on probiotic strains exposed to simulated gastrointestinal conditions. Food Res Int 44:465-470

Magno MB, Nadelman P, De Abreu Brandi TC, Pithon MM, FonsecaGonçalves A, Da Cruz AG, Maia LC (2019). The effect of dairy probiotic beverages on oral health. In Milk-based beverages, 521556. Woodhead Publishing

Moreira ACA, Pereira MHQ, Porto MR, Rocha LD, Nascimento BC, Andrade PM (2009) Avaliação in vitro da atividade antimicrobiana de antissépticos bucais. Revista de Ciências Médicas e Biológicas 8(2):153-161

Oberg CJ, Wang A, Moyes LV, Brown RJ, Richardson GH (1991) Effects of proteolytic activity of thermolactic cultures on physical properties of ozzarella cheese. Journal Dairy Science 74:389-397 
Padmavathi T, Bhargavi R, Priyanka PR, Niranjan NR, Pavitra PV (2018) Screening of potential probiotic lactic acid bacteria and production of amylase and its partial purification. Journal of Genetic Engineering and Biotechnology 16(2):357-362

Patel A, Prajapati JB, Holst O, Ljungh A (2014) Determining probiotic potential of exopolysaccharide producing lactic acid bacteria isolated from vegetables and traditional Indian fermented food products. Food Biosci 5:27-33

Pedersen TB, Ristagno D, McSweeney PLH, Vogensen FK, Ardö Y (2013) Potential impact on cheese flavour of heterofermentative bacteria from starter cultures. Int Dairy J 33(2):112-119

Ren D, Li C, Qin Y, Yin R, Du S, Ye F, Sun Y (2014) In vitro evaluation of the probiotic and functional potential of Lactobacillus strains isolated from fermented food and human intestine. Anaerobe 30: $1-10$

Saadat YR, Khosroushahi AY, Gargari BP (2019) A comprehensive review of anticancer, immunomodulatory and health beneficial effects of the lactic acid bacteriaexopolysaccharides. Carbohydr Polym 217:79-89

Saelim K, Jampaphaeng K, Maneerat S (2017) Functional properties of Lactobacillus plantarum $\mathrm{S} 0 / 7$ isolated fermented stinky bean ( $\mathrm{Sa}$ taw dong) and its use as a starter culture. J Funct Foods 38:370-377

Samot J, Badet C (2013) Antibacterial activity of probiotic candidates for oral health. Anaerobe 19:34-38

Schiavao-Souza TD, Yuhara TT, Castro-Gómez RJH, Garcia S (2007) Produção de exopolissacarídeos por bactérias probióticas: otimização do meio de cultura. Brazilian Journal of Food Technology 10(1):27-34

Shehata MG, El Sohaimy SA, El-Sahn MA, Youssef MM (2016) Screening of isolated potential probiotic lactic acid bacteria for cholesterol lowering property and bile salt hydrolase activity. Annals of Agricultural Sciences 61(1):65-75

Schwendicke F, Korte F, Dörfer CE, Kneist S, El-Sayed KF, Paris S (2017) Inhibition of Streptococcus mutans growth and biofilm formation by probiotics in vitro. Caries Res 51(2):87-95

Silva LA, Lopes Neto JHP, Cardarelli HR (2019) Exopolysaccharides produced by Lactobacillus plantarum: technological properties, biological activity, and potential application in the food industry. Ann Microbiol 69(4):321-328

Taipale T, Pienihäkkinen K, Salminen S, Jokela J, Söderling E (2012) Bifidobacterium animalis subsp. lactis BB-12 administration in early childhood: a randomized clinical trial of effects on oral colonization by mutans streptococci and the probiotic. Caries Res 46(1):69-77

Tavares VB, Pinto JC, Evangelista AR, Figueiredo HCP, Ávila CLDS (2009) Effects of different compaction degrees, inclusion of absorbent additive and wilting on the chemical composition of Tanzania grass silages. Rev Bras Zootec 38(1):40-49

Todorov SD, Botes M, Guigas C, Schillinger U, Wiid I, Wachsman MB, Dicks LMT (2008) Boza, a natural source of probiotic lactic acid bacteria. J Appl Microbiol 104(2):465-477

Todorov SD, Furtado DN, Saad SMI, Tome E, Franco BDGM (2011) Potential beneficial properties of bacteriocin producing lactic acid bacteria isolated from smoked salmon. J Appl Microbiol 110(4): 971-986

Reenen V (1998) Isolation, purification and partial characterization of plantaricin 423 , a bacteriocin produced by Lactobacillus plantarum. J Appl Microbiol 84(6):1131-1137

Verón HE, Di Risio HD, Isla MI, Torres S (2017) Isolation and selection of potential probiotic lactic acid bacteria from Opuntia ficus-indica fruits that grow in Northwest Argentina. LWT- Food Science and Technology 84:231-240

Vijaya KBV, Vijayendra SVN, Reddy OVS (2015) Trends in dairy and non-dairy probiotic products-a review. J Food Sci Technol 52(10): 6112-6124

Vinderola G, Capellini B, Villarreal F, Suárez V, Quiberoni A, Reinheimer J (2008) Usefulness of a set of simple in vitro tests for the screening and identification of probiotic candidate strains for dairy use. LWT Food Sci Technol 41(9):1678-1688

Xu H, Jeong HS, Lee HY, Ahn J (2009) Assessment of cell surface properties and adhesion potential of selected probiotic strains. Lett Appl Microbiol 49(4):434-442

Xu Z, Li L, Shirtliff ME, Peters BM, Peng Y, Alam MJ, Shi L (2010) First report of class 2 integron in clinical Enterococcus faecalis and class 1 integron in Enterococcus faecium in South China. Diagn Microbiol Infect Dis 68(3):315-317

Yogurtcu NN, Tuncer Y (2013) Antibiotic susceptibility patterns of Enterococcus strains isolated from Turkish Tulum cheese. Int $\mathbf{J}$ Dairy Technol 66(2): 236-242.

Publisher's note Springer Nature remains neutral with regard to jurisdictional claims in published maps and institutional affiliations. 